\title{
Stability of Azacitidine in Sterile Water for Injection
}

\author{
Scott E Walker, Lauren F Charbonneau, Shirley Law, and Craig Earle
}

\begin{abstract}
Background: The product monograph for azacitidine states that once reconstituted, the drug may be held for only $30 \mathrm{~min}$ at room temperature or $8 \mathrm{~h}$ at $4^{\circ} \mathrm{C}$. Standard doses result in wastage of a portion of each vial, and the cost of this wastage is significant, adding about $\$ 156000$ to annual drug expenditures at the authors' institution.
\end{abstract}

Objective: To evaluate the stability of azacitidine after reconstitution.

Methods: Vials of azacitidine were reconstituted with sterile water for injection. At the time of reconstitution, the temperature of the diluent was $4^{\circ} \mathrm{C}$ for samples to be stored at $4^{\circ} \mathrm{C}$ or $-20^{\circ} \mathrm{C}$ and room temperature for samples to be stored at $23^{\circ} \mathrm{C}$. Solutions of azacitidine ( 10 or 25 $\mathrm{mg} / \mathrm{mL}$ ) were stored in polypropylene syringes and glass vials at room temperature $\left(23^{\circ} \mathrm{C}\right), 4^{\circ} \mathrm{C}$, or $-20^{\circ} \mathrm{C}$. The concentration of azacitidine was determined by a validated, stability-indicating liquid chromatographic method in serial samples over $9.6 \mathrm{~h}$ at room temperature, over 4 days at $4^{\circ} \mathrm{C}$, and over 23 days at $-20^{\circ} \mathrm{C}$. The recommended expiry date was determined on the basis of time to reach $90 \%$ of the initial concentration according to the fastest observed degradation rates (i.e., lower limit of $95 \%$ confidence interval).

Results: Azacitidine degradation was very sensitive to temperature but not storage container (glass vial or polypropylene syringe). Reconstitution with cold sterile water reduced degradation. At $23^{\circ} \mathrm{C}, 15 \%$ of the initial concentration was lost after $9.6 \mathrm{~h}$; at $4^{\circ} \mathrm{C}, 32 \%$ was lost after 4 days; and at $-20^{\circ} \mathrm{C}$, less than $5 \%$ was lost after 23 days.

Conclusions: More than $90 \%$ of the initial azacitidine concentration will be retained, with $97.5 \%$ confidence, if, during the life of the product, storage at $23^{\circ} \mathrm{C}$ does not exceed $2 \mathrm{~h}$, storage at $4^{\circ} \mathrm{C}$ does not exceed $8 \mathrm{~h}$, and storage at $-20^{\circ} \mathrm{C}$ does not exceed 4 days. These expiry dates could substantially reduce wastage and cost where the time between doses does not exceed 4 days.

Key words: azacitidine, drug stability

Can J Hosp Pharm 2012;65(5):352-359

\section{RÉSUMÉ}

Contexte : La monographie de l'azacitadine mentionne que, une fois le médicament reconstitué, on peut le conserver pendant seulement 30 minutes à la température ambiante ou huit heures à $4{ }^{\circ} \mathrm{C}$. Des doses standards entraînent donc le gaspillage d'une partie de chaque flacon et le coût de ce gaspillage est considérable, ajoutant environ 156000 \$ au coût d'acquisition annuel des médicaments à l'établissement de l'auteur.

Objectif : Évaluer la stabilité de l'azacitidine après sa reconstitution.

Méthodes: On a reconstitué le contenu de flacons d'azacitidine avec de l'eau stérile pour injection. Au moment de la reconstitution, la température du diluant était de $4{ }^{\circ} \mathrm{C}$ pour les échantillons devant être conservés à $4{ }^{\circ} \mathrm{C}$ ou $-20^{\circ} \mathrm{C}$ et à la température ambiante pour les échantillons devant être conservés à $23^{\circ} \mathrm{C}$. Les solutions d'azacitidine $(10$ ou $25 \mathrm{mg} / \mathrm{mL}$ ) ont été conservées dans des seringues de polypropylène et des flacons de verre entreposés à la température ambiante $\left(23^{\circ} \mathrm{C}\right)$, à $4{ }^{\circ} \mathrm{C}$ ou à $-20^{\circ} \mathrm{C}$. La concentration d'azacitidine a été déterminée à l'aide d'une épreuve validée par chromatographie liquide haute performance mesurant la stabilité dans des échantillons séquentiels pendant une période de $9,6 \mathrm{~h}$ à la température ambiante, de quatre jours à $4{ }^{\circ} \mathrm{C}$ et de 23 jours à $-20^{\circ} \mathrm{C}$. La durée limite de conservation recommandée a été déterminée en fonction du temps écoulé jusquà ce que la concentration d'azacitidine dans l'échantillon atteigne $90 \%$ de sa valeur initiale d'après la vitesse de dégradation observée la plus rapide (c.-à-d. limite inférieure de l'intervalle de confiance à $95 \%$ ).

Résultats : La dégradation de l'azacitidine était très sensible à la température, mais non au contenant (flacon de verre ou seringue de polypropylène). La reconstitution avec de l'eau stérile froide a réduit la dégradation. À la température de $23{ }^{\circ} \mathrm{C}$, la solution a perdu $15 \%$ de sa concentration initiale après $9,6 \mathrm{~h}$; à la température de $4^{\circ} \mathrm{C}$, elle en a perdu $32 \%$ après quatre jours; et à la température de $-20^{\circ} \mathrm{C}$, elle a perdu moins de $5 \%$ de la concentration initiale après 23 jours.

Conclusions: La solution reconstituée conservera plus de $90 \%$ de sa concentration initiale d'azacitidine, avec un intervalle de confiance à $97,5 \%$, si durant la vie du produit, la période de conservation à $23^{\circ} \mathrm{C}$ ne dépasse pas deux heures; à $4^{\circ} \mathrm{C}$, elle ne dépasse pas 8 heures; et à $-20^{\circ} \mathrm{C}$, elle ne dépasse pas 4 jours. Ces durées limites de conservation pourraient réduire sensiblement le gaspillage et les coûts lorsque l'intervalle d'administration des doses ne dépasse pas quatre jours.

Mots clés : azacitidine, stabilité des médicaments

[Traduction par l'éditeur] 


\section{INTRODUCTION}

$\mathrm{T}$ he expiry date of IV medications following reconstitution or dilution is often limited to about $24 \mathrm{~h}$ because of the potential for breaks in sterility. However, when reconstitution and dilution are carried out in a sterile environment following United States Pharmacopeia Chapter <797> recommendations, it is entirely reasonable to extend the expiry dates of these products from $24 \mathrm{~h}$ to 10 or even 14 days, provided there are no stability or physicochemical issues with the product. ${ }^{1}$ For many drugs, extending the expiry date may reduce wastage ${ }^{2,3}$ and may increase convenience for ambulatory patients, eliminating frequent returns to a clinic for additional doses.

Azacitidine is a nucleoside metabolic inhibitor indicated for the treatment of patients with the following $F A B$ (French-American-British) myelodysplastic syndrome subtypes: refractory anemia, refractory anemia with ringed sideroblasts (if accompanied by neutropenia or thrombocytopenia or requiring transfusions), refractory anemia with excess blasts, refractory anemia with excess blasts in transformation, and chronic myelomonocytic leukemia. ${ }^{4}$

For all patients, regardless of baseline hematology laboratory values, the recommended starting dose for the first treatment cycle is $75 \mathrm{mg} / \mathrm{m}^{2}$ daily, either subcutaneously or intravenously, for 7 days. ${ }^{4}$ Azacitidine for injection is supplied as a lyophilized powder in $100-\mathrm{mg}$, single-use vials. ${ }^{4}$ For subcutaneous use, the product is reconstituted with $4 \mathrm{~mL}$ of sterile water for injection to prepare a $25 \mathrm{mg} / \mathrm{mL}$ suspension. For IV use, it is reconstituted with $10 \mathrm{~mL}$ of sterile water for injection to prepare a $10 \mathrm{mg} / \mathrm{mL}$ solution. Given the recommended dose and the amount of drug supplied in each single-use vial, most doses require more than a single vial but less than 2 vials, such that a portion of a vial remains after the dose has been given. Even if multiple patients present for treatment on the same day, a portion of a vial will likely remain at the end of each day.

The product monograph indicates that the reconstituted drug should be kept in the vial or drawn into a syringe and that it must be refrigerated immediately and may then be held under refrigerated conditions $\left(2^{\circ} \mathrm{C}\right.$ to $8^{\circ} \mathrm{C}\left[36^{\circ} \mathrm{F}\right.$ to $\left.\left.46^{\circ} \mathrm{F}\right]\right)$ for up to $8 \mathrm{~h} .^{4}$ After removal from refrigeration, the suspension may be allowed to equilibrate to room temperature for up to 30 min before administration. ${ }^{4}$ The instability of azacitidine is supported by the 1984 report by Cheung and others, ${ }^{5}$ who reported degradation time to reach $90 \%$ of initial concentration, for a $2 \mathrm{mg} / \mathrm{mL}$ solution, as $2.4 \mathrm{~h}$ in saline and $3 \mathrm{~h}$ in $5 \%$ dextrose in water. These authors also reported that the time to reach $90 \%$ of initial concentration was shorter for less concentrated solutions. ${ }^{5}$

Beyond-use times of $30 \mathrm{~min}$ at room temperature and $8 \mathrm{~h}$ at $4^{\circ} \mathrm{C}$ are problematic from a dispensing perspective. Patients with myelodysplastic syndrome are treated daily, and a portion of a second 100-mg vial typically remains following each dose. Therefore, daily wastage is substantial and was estimated to cost about $\$ 156000$ annually at the authors' institution.

The objective of this study was to evaluate the physical and chemical stability of 2 concentrations of azacitidine after reconstitution in cold sterile water, with the ultimate goal of reducing azacitidine wastage. Cold sterile water was used for reconstitution on the basis of the report by Tutino and $\mathrm{Lai}^{6}$ that this diluent reduces the degradation rate.

\section{METHODS}

\section{Liquid Chromatographic Method}

The liquid chromatographic system consisted of an isocratic solvent delivery pump (model P4000, Thermo Separation Products, San Jose, California), which pumped 0.05 $\mathrm{mol} / \mathrm{L}$ potassium phosphate dibasic (catalogue no. 191431, MP Biomedicals, Solon, Ohio; lot 9761K) adjusted to $\mathrm{pH} 7$ with $85 \%$ high-performance liquid chromatography-grade phosphoric acid (Fisher Scientific, Toronto, Ontario; lot 076856) through a $30 \mathrm{~cm} \times 3.9 \mathrm{~mm}$ reversed-phase $\mathrm{C}_{18}, 5-\mu \mathrm{m}$ column (Waters Nova Pak column, Waters, Mississauga, Ontario) at $1.0 \mathrm{~mL} / \mathrm{min}$. The samples were introduced into the liquid chromatographic system using an autoinjector (WISP 717-Plus, Waters, Mississauga, Ontario).

The column effluent was monitored with a variablewavelength photodiode array detector (UV6000, Thermo Separation Products) at $245 \mathrm{~nm}$. A signal from the detector was integrated and recorded with a chromatography data system (Chrom Quest, version 5.0, ThermoFisher Scientific Inc, Nepean, Ontario). The area under the azacitidine peak was subjected to least-squares linear regression, and the actual azacitidine concentration in each sample was determined by interpolation from the standard curve.

\section{Assay Validation}

Following development of the chromatographic system for azacitidine, the suitability of this method for use as a stabilityindicating assay was tested by analysis of azacitidine samples subjected to accelerated degradation. ${ }^{-9}$ A $10-\mathrm{mg}$ sample of azacitidine (Vidaza $100 \mathrm{mg}$ azacitidine for injection, Celgene Canada Ltd, Mississauga, Ontario; lot OC300AA, expiry February 2014) was diluted in $10 \mathrm{~mL}$ of distilled water to prepare a $1 \mathrm{mg} / \mathrm{mL}$ solution. A portion of this stock solution was placed directly into an empty, sterile 2-mL vial (Allergy Laboratory Inc, Oklahoma City, Oklahoma; lot SEV100209). A $0.1-\mathrm{mL}$ sample was drawn immediately, and the vial was then placed in a water bath at $80^{\circ} \mathrm{C}$. Additional $0.1-\mathrm{mL}$ samples were drawn at 5 different times over a 221 -min period. A second $2-\mathrm{mL}$ portion of the $1 \mathrm{mg} / \mathrm{mL}$ stock solution of azacitidine, adjusted to $\mathrm{pH} 11.05$ with $1 \mathrm{~mol} / \mathrm{L}$ sodium 
hydroxide (Fisher Scientific), was placed directly into an empty, sterile 2 -mL vial, and a $0.1-\mathrm{mL}$ sample was drawn immediately. This vial was kept at room temperature $\left(23^{\circ} \mathrm{C}\right)$, and additional $0.1-\mathrm{mL}$ samples were drawn at 6 different times over a 192-min period. A third 2-mL portion of the $1 \mathrm{mg} / \mathrm{mL}$ stock solution of azacitidine, adjusted to $\mathrm{pH} 2.09$ with $0.5 \mathrm{~mol} / \mathrm{L}$ hydrochloric acid (Fisher Scientific), was placed directly into an empty, sterile 2-mL vial, and a $0.1-\mathrm{mL}$ sample was drawn immediately. This vial was also kept at room temperature, and additional 0.1 - $\mathrm{mL}$ samples were drawn at 7 different times over a 146 -min period. From each of the $0.1-\mathrm{mL}$ samples, $4.0-\mu \mathrm{L}$ volumes were injected directly into the chromatographic system with the autoinjector. Chromatograms were inspected for the appearance of additional peaks, and the azacitidine peak was compared with a fresh, undegraded sample in terms of changes in concentration, retention time, peak shape, and ultraviolet (UV) spectral purity (over the wavelength range 200-320 nm).

Following this first phase of evaluation and validation, the accuracy and reproducibility of standard curves were tested over 5 days, and system suitability criteria (theoretical plates, tailing, and retention time) were developed to ensure consistent chromatographic performance, according to accepted analytical guidelines. ${ }^{10}$ Standard curves were prepared daily by weighing $10 \mathrm{mg}$ of azacitidine (Vidaza $100 \mathrm{mg}$ azacitidine for injection single-use vial, Celgene Canada Ltd.; lot 1D383B, expiry March 2015) and diluting this quantity of drug in $10 \mathrm{~mL}$ of distilled water. This stock solution of $1 \mathrm{mg} / \mathrm{mL}(1000 \mu \mathrm{g} / \mathrm{mL})$ was further diluted with distilled water to prepare additional standards with final concentrations of 750.0, 375.0, 187.5, and $93.8 \mu \mathrm{g} / \mathrm{mL}$. When combined with a blank, these standards served to construct a standard curve. A $4-\mu \mathrm{L}$ portion of each sample was chromatographed in duplicate. Also, 3 quality control samples of azacitidine (concentrations 500.0, 250.0, and $125 \mu \mathrm{g} / \mathrm{mL}$ ) were chromatographed in duplicate each day, and their concentrations were determined and compared with the known concentrations. Intraday errors of reproducibility were assessed by the coefficients of variation of the peak areas of both the quality control samples and the standards. Accuracy was assessed each day on the basis of deviation from known concentration and was expressed as percent deviation. During the study period, interday errors of reproducibility were assessed by the standard deviation of regression, expressed as a percentage relative to the concentration.

\section{Stability Study: Vials at $23^{\circ} \mathrm{C}$}

On study day 0 , the contents of two 100 -mg vials of azacitidine (Vidaza $100 \mathrm{mg}$ azacitidine for injection single-use vial, Celgene Canada Ltd; lot 1D383B, expiry March 2015) were reconstituted with sterile water for injection (Hospira Health Care, Montréal, Quebec; lot 11-620-43-01, expiry November 1, 2014) at room temperature. One single-use vial was reconstituted with $10 \mathrm{~mL}$ of sterile water. Two portions of the contents of this vial were transferred into empty, sterile 10 -mL vials (Allergy Laboratories Inc), such that a total of 3 vials were prepared, each containing $3.3 \mathrm{~mL}$ of azacitidine $10 \mathrm{mg} / \mathrm{mL}$. The second single-use vial was reconstituted with $4 \mathrm{~mL}$ of sterile water. Two portions of the contents of this vial were transferred into empty, sterile $10-\mathrm{mL}$ vials (Allergy Laboratories Inc), such that a total of 3 vials were prepared, each containing $1.3 \mathrm{~mL}$ of azacitidine $25 \mathrm{mg} / \mathrm{mL}$.

All 6 vials were stored at room temperature $\left(23^{\circ} \mathrm{C}\right)$. The samples were not protected from light. Immediately following reconstitution and at $2.4 \mathrm{~h}, 4.8 \mathrm{~h}, 7.2 \mathrm{~h}$, and $9.6 \mathrm{~h}$ following reconstitution the concentration of azacitidine was determined in duplicate, and visual inspection was performed.

At each sampling time on the study day, a small volume was drawn from each container. For solutions with a nominal concentration of $10 \mathrm{mg} / \mathrm{mL}$, a $0.5-\mathrm{mL}$ sample was transferred by pipette into a $5-\mathrm{mL}$ volumetric flask. For suspensions with a nominal concentration of $25 \mathrm{mg} / \mathrm{mL}$, a $0.2-\mathrm{mL}$ sample was transferred by pipette into a $5-\mathrm{mL}$ volumetric flask. Each sample was diluted with distilled water to a total volume of $5 \mathrm{~mL}$. Duplicate $4-\mu \mathrm{L}$ samples were injected directly into the chromatographic system.

\section{Stability Study: Vials and Syringes at $4^{\circ} \mathrm{C}$}

On study day 0 , the contents of four 100 -mg vials of azacitidine were reconstituted with cold $\left(4^{\circ} \mathrm{C}\right)$ sterile water for injection. Two of the vials were reconstituted with $10 \mathrm{~mL}$ of sterile water to prepare a $10 \mathrm{mg} / \mathrm{mL}$ solution. Two portions of the contents of one of these vials were transferred into empty, sterile $10-\mathrm{mL}$ vials, such that a total of 3 vials were prepared, each containing $3.3 \mathrm{~mL}$ of azacitidine $10 \mathrm{mg} / \mathrm{mL}$. The contents of the second vial reconstituted with $10 \mathrm{~mL}$ of sterile water were divided among three $5-\mathrm{mL}$ polypropylene syringes $(\mathrm{BD}$, Franklin Lakes, New Jersey), each containing $3.3 \mathrm{~mL}$. The third and fourth 100-mg vials were each reconstituted with 4 $\mathrm{mL}$ of sterile water to prepare $25 \mathrm{mg} / \mathrm{mL}$ suspensions. Two portions of the contents of one of these vials were transferred into 2 empty, sterile $10-\mathrm{mL}$ vials (Allergy Laboratories Inc), such that a total of 3 vials were prepared, each containing $1.3 \mathrm{~mL}$ of azacitidine $25 \mathrm{mg} / \mathrm{mL}$. The contents of the other vial reconstituted with $4 \mathrm{~mL}$ of sterile water were divided among three 5 -mL syringes, each containing $1.3 \mathrm{~mL}$.

All 6 vials and all 6 syringes were stored in the refrigerator at $4^{\circ} \mathrm{C}$. The samples were not protected from light. Immediately following reconstitution and on days 1,3 , and 4 , the concentration of azacitidine was determined in duplicate, and visual inspection was performed.

On each study day, a small volume was drawn from each container. For solutions with a nominal concentration of $10 \mathrm{mg} / \mathrm{mL}$, a $0.5-\mathrm{mL}$ sample was transferred by pipette into a 
5-mL volumetric flask. For suspensions with a nominal concentration of $25 \mathrm{mg} / \mathrm{mL}$, a $0.2-\mathrm{mL}$ sample was transferred by pipette into a $5-\mathrm{mL}$ volumetric flask. Each sample was diluted with distilled water to a total volume of $5 \mathrm{~mL}$. Duplicate $4-\mu \mathrm{L}$ samples were injected directly into the chromatographic system.

\section{Stability Study: Vials and Syringes at $-20^{\circ} \mathrm{C}$}

On study day 0 , the contents of seven $100-\mathrm{mg}$ vials of azacitidine were reconstituted with cold $\left(4^{\circ} \mathrm{C}\right)$ sterile water for injection. Two of the vials were reconstituted with $10 \mathrm{~mL}$ of sterile water to prepare $10 \mathrm{mg} / \mathrm{mL}$ solutions. From the first of these vials, portions of no less than $0.4 \mathrm{~mL}$ were transferred into each of 24 empty, sterile 2-mL glass vials (Allergy Laboratories Inc) to prepare 24 vials of azacitidine $10 \mathrm{mg} / \mathrm{mL}$. The contents of the second vial with $10 \mathrm{mg} / \mathrm{mL}$ solution were divided among 24 polypropylene 5 -mL syringes (BD, Franklin Lakes, New Jersey), with each syringe containing no less than $0.4 \mathrm{~mL}$. The other 5 vials were each reconstituted with $4 \mathrm{~mL}$ of sterile water to prepare $25 \mathrm{mg} / \mathrm{mL}$ suspensions. The contents of the 5 vials were combined and then divided between 2 of the vials, to yield 2 vials each containing $10 \mathrm{~mL}$ of the $25 \mathrm{mg} / \mathrm{mL}$ suspension. Each $10-\mathrm{mL}$ volume was mixed well. The contents of one vial were divided among 24 empty, sterile 2-mL glass vials (Allergy Laboratories Inc), such that each vial contained approximately $0.4 \mathrm{~mL}$ of $25 \mathrm{mg} / \mathrm{mL}$ of azacitidine suspension. The contents of the second vial containing $10 \mathrm{~mL}$ of the $25 \mathrm{mg} / \mathrm{mL}$ suspension were divided among 24 polypropylene 5 -mL syringes $(\mathrm{BD})$, such that each syringe contained no less than $0.4 \mathrm{~mL}$ of azacitidine $25 \mathrm{mg} / \mathrm{mL}$.

All 48 vials and 48 syringes were stored in a freezer at $-20^{\circ} \mathrm{C}$. The samples were not protected from light. Immediately following reconstitution and on days 1, 6, 13, 18, 20, and 23 , the concentration of azacitidine was determined in duplicate, and visual inspection was performed.

On each study day, 6 syringes (3 syringes containing $10 \mathrm{mg} / \mathrm{mL}$ and 3 containing $25 \mathrm{mg} / \mathrm{mL}$ ) and 6 vials (3 vials containing $10 \mathrm{mg} / \mathrm{mL}$ and 3 containing $25 \mathrm{mg} / \mathrm{mL}$ ) were withdrawn from the freezer and thawed. For each solution with a nominal concentration of $10 \mathrm{mg} / \mathrm{mL}$, a $0.2-\mathrm{mL}$ sample was transferred by pipette into a $2-\mathrm{mL}$ volumetric flask. Each sample was diluted with distilled water to a total volume of $2 \mathrm{~mL}$. For suspensions with a nominal concentration of $25 \mathrm{mg} / \mathrm{mL}$, a $0.2-\mathrm{mL}$ sample was transferred by pipette into a 5 -mL volumetric flask. Each sample was diluted with distilled water to a total volume of $5 \mathrm{~mL}$. Duplicate $4-\mu \mathrm{L}$ samples were injected directly into the chromatographic system.

\section{Data Reduction and Statistical Analysis}

After the coefficient of variation of replicate determinations of concentration for an assay was determined, a power calculation indicated that 2 replicates would be required to ensure that the analytical method could distinguish between concentrations that differed by at least $10 \% .^{11,12}$ Means were calculated for replicate analyses and are reported in the summary tables. Mean results from different days for each test were compared statistically (by linear regression) to determine if there was an association between the observed result and time. Analysis of variance was used to test differences in degradation rate between various container-concentration combinations. The $5 \%$ level was used as the a priori cut-off for significance. The concentration of a solution on a particular day was considered "acceptable" or "within acceptable limits" if it was greater than $90 \%$ of the initial concentration (as determined on day 0 ) and if the amount found on that day, with $95 \%$ confidence, exceeded $90 \%$ of the initial concentration.

\section{RESULTS}

\section{Accelerated Degradation and Assay Validation}

Azacitidine degrades quickly, even without acid, base, or heat. When a $1 \mathrm{mg} / \mathrm{mL}$ solution was incubated with heat $\left(80^{\circ} \mathrm{C}\right)$, a single degradation product was observed (Figure 1), as previously reported. ${ }^{5}$ During the 221-min study period for this aspect of the degradation study, the concentration of azacitidine declined rapidly, to less than $81.5 \%$ in $12 \mathrm{~min}$. After $161 \mathrm{~min}$, only $23 \%$ of the original concentration remained, and at the end of the 221-min degradation period, only $16 \%$ remained. At room temperature, degradation under acidic conditions was also rapid, such that only $49 \%$ of the original concentration remained after $146 \mathrm{~min}$. Under alkaline conditions, also at room temperature, degradation was slightly faster, such that only $30 \%$ remained after $130 \mathrm{~min}$ and about $15 \%$ remained at the last sampling time of $192 \mathrm{~min}$.

Throughout this evaluation, the azacitidine peak in the degraded samples had a UV spectrum identical with that of the authentic azacitidine sample. As a result of consistent degradation of azacitidine with heat, acid, and base, the separation of azacitidine and the observed degradation product, and the similarity of the UV spectrum (200-320 nm) between a fresh azacitidine sample and azacitidine in the degraded samples, it was concluded that this analytical method was stabilityindicating. ${ }^{7-9}$

Assay validation demonstrated that absolute deviation from the known concentration averaged $4.25 \%$. The error of replicate analysis within a day averaged less than $3.90 \%$ for the standards and less than $2.99 \%$ for the quality control samples.

The analysis of accuracy based on the means of duplicate determinations of standards over the study period showed less than $3.4 \%$ absolute deviation from the expected concentration. The error of replicate analysis within a day (as measured by the 
coefficient of variation) averaged less than $2.0 \%$ for the standards. Interday variation, as measured by the observed standard deviation of regression for percent remaining, was $2.5 \%$. This value indicates that differences of $10 \%$ or more could be confidently detected with acceptable error rates, ${ }^{11,12}$ with duplicate analysis. System suitability criteria were based on daily calculations of theoretical plates, tailing, retention time, and accuracy during the validation period and were used to ensure continued chromatographic performance during the study period. On each day, the mobile phase was prepared to ensure a retention time for azacitidine between 3.9 and $4.3 \mathrm{~min}$.

\section{Stability of Azacitidine at Room Temperature $\left(23^{\circ} \mathrm{C}\right)$}

During the 9.6-h room temperature study, there was about $10 \%$ loss within $5 \mathrm{~h}$ (Table 1). Degradation products were observed in samples obtained over the 9.6-h study period. Analysis of variance revealed differences in percent remaining due to study day $(p<0.001)$ but not concentration $(p=0.40)$.

The data were also analyzed by linear regression, and the time for the solution to decline to $90 \%$ of initial concentration (T-90) was calculated for each concentration. When the 95\% confidence limits for the degradation rates were used to estimate T-90, a beyond-use date of $4.6 \mathrm{~h}$ or longer was calculated for solutions reconstituted according to the product monograph.

\section{Stability of Azacitidine at $4^{\circ} \mathrm{C}$}

During the 4-day refrigeration study, there was more than $30 \%$ loss (Table 2). Degradation products were observed in all samples (Figure 2). Analysis of variance revealed differences in percent remaining due to study day $(p<0.001)$, concentration ( $p=0.033)$, and storage container $(p=0.010)$. More specifically, solutions with initial concentration of $10 \mathrm{mg} / \mathrm{mL}$ degraded faster than suspensions with initial concentration of $25 \mathrm{mg} / \mathrm{mL}$. However, after $24 \mathrm{~h}$, the concentration in the $10 \mathrm{mg} / \mathrm{mL}$ solutions would be approximately $1 \%$ lower than the concentration in the $25 \mathrm{mg} / \mathrm{mL}$ suspensions. Similarly, azacitidine stored in syringes degraded faster than azacitidine stored in vials, but again this would translate into a very small difference. After $24 \mathrm{~h}$, the concentration of suspensions stored in syringes would be less than $1 \%$ lower than the concentration of suspensions stored in the manufacturer's original vials.

The data were also analyzed by linear regression, and T-90 was calculated for each concentration-container combination. When the 95\% confidence limits for the degradation rates were used to estimate T-90, a beyond-use date of $22 \mathrm{~h}$ or longer was calculated for solutions reconstituted with cold $\left(4^{\circ} \mathrm{C}\right)$ sterile water for injection (Table 2).

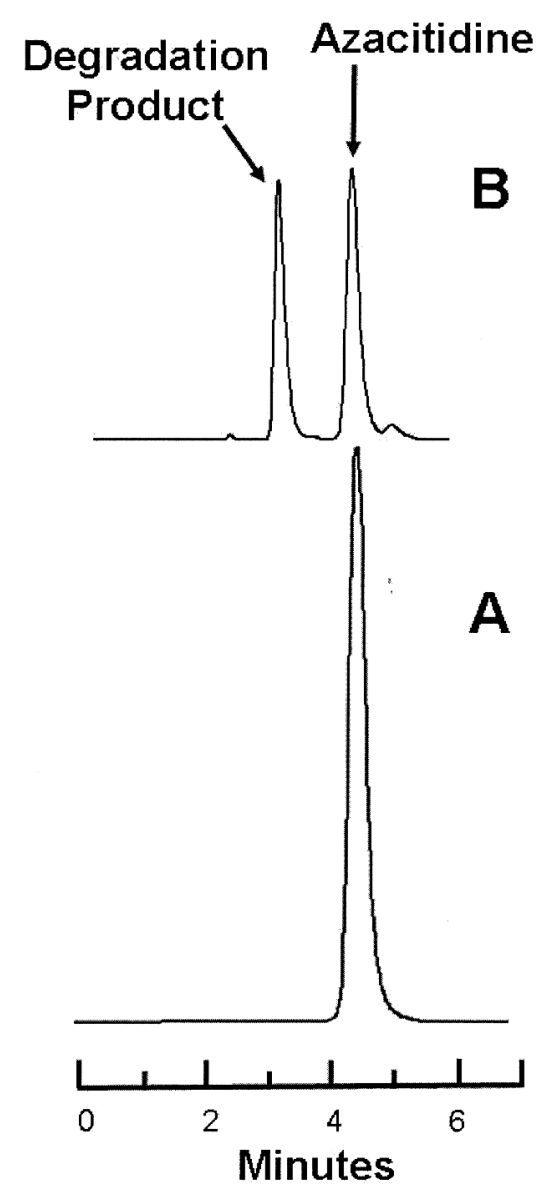

Figure 1. Representative chromatograms obtained during the degradation studies. Lower panel (A): Azacitidine 1 $\mathrm{mg} / \mathrm{L}$ in water at time 0 . Upper panel (B): The same sample of azacitidine $1 \mathrm{mg} / \mathrm{mL}$ after incubation at $80^{\circ} \mathrm{C}$ for 65 min, at which time $47 \%$ of the initial concentration remained. Azacitidine eluted at $4.2 \mathrm{~min}$, and the largest degradation product eluted at $3.1 \mathrm{~min}$.

\section{Stability of Azacitidine at $-20^{\circ} \mathrm{C}$}

During the 23-day period of frozen storage, there was no apparent loss of azacitidine concentration for solutions and suspensions stored in glass vials or polypropylene syringes (Table 3). Furthermore, no degradation was seen over the period of the study and, therefore, in all likelihood, the product showed acceptable stability for at least 23 days.

Analysis of variance revealed no significant differences in percent remaining due to study day $(p=0.50)$, concentration $(p=0.67)$, or container $(p=0.44)$.

When the $95 \%$ confidence limits for the degradation rates were used to estimate T-90, a beyond-use date of 20 days or longer was calculated for solutions reconstituted with cold $\left(4^{\circ} \mathrm{C}\right)$ sterile water for injection. 
Table 1. Percentage of Azacitidine Remaining* after Storage in Vials at Room Temperature $\left(23^{\circ} \mathrm{C}\right)$

\begin{tabular}{|c|c|c|}
\hline \multirow{2}{*}{ Study Hour } & \multicolumn{2}{|c|}{ Initial Concentration; Mean \% Remaining \pm SD } \\
\hline & Nominal & Nominal \\
\hline Initial concentration, observed $(\mathrm{mg} / \mathrm{mL})$ & $29.35 \pm 0.11$ & $11.25 \pm 0.14$ \\
\hline $2.4 \mathrm{~h}$ & $93.06 \pm 1.17$ & $92.68 \pm 0.84$ \\
\hline $4.8 \mathrm{~h}$ & $89.98 \pm 1.86$ & $90.75 \pm 1.30$ \\
\hline $7.2 \mathrm{~h}$ & $87.89 \pm 1.68$ & $87.76 \pm 1.19$ \\
\hline $9.6 \mathrm{~h}$ & $84.34 \pm 0.20$ & $85.35 \pm 0.48$ \\
\hline \multicolumn{3}{|l|}{ Data analysis } \\
\hline Degradation rate $(\% / h) \dagger$ & -1.520 & -1.426 \\
\hline SD from regression $(S y . x) \neq$ & 1.544 & 1.704 \\
\hline Fastest degradation rate (\% loss $/ \mathrm{h}$ ) with $95 \%$ confidence§ & -2.168 & -2.141 \\
\hline Shortest T-90 (h) with 95\% confidence §ף & 4.61 & 4.67 \\
\hline
\end{tabular}

$\mathrm{Cl}=$ confidence interval, $\mathrm{SD}=$ standard deviation.

*Each value is based on duplicate determination of 3 samples. The percent remaining is based on designation of the initial measured concentration as $100 \%$.

†The degradation rate was determined by linear regression of the percent remaining at each study time. ¥The SD from the regression (Sy.x) provides an estimate of the SD about the line determined by linear regression, expressed as a percentage relative to the concentration. Expressed in this way, it is also an estimate of the between-day error of replicate analysis.

$\S$ The fastest degradation rate was determined from the lower limit of the $95 \% \mathrm{Cl}$ of the slope (percent remaining versus study hour) determined by linear regression.

१T-90 is the time for the concentration to decline by $10 \%$, i.e., to $90 \%$ of the initial concentration.

Table 2. Percentage of Azacitidine Remaining* with Storage at $4^{\circ} \mathrm{C}$

Type of Container; Initial Concentration; Mean \% Remaining \pm SD

\begin{tabular}{|c|c|c|c|c|}
\hline \multirow[b]{2}{*}{ Study Day } & \multicolumn{2}{|c|}{ Vials } & \multicolumn{2}{|c|}{ Syringes } \\
\hline & $\begin{array}{l}\text { Nominal } \\
25 \mathrm{mg} / \mathrm{mL}\end{array}$ & $\begin{array}{l}\text { Nominal } \\
10 \mathrm{mg} / \mathrm{mL}\end{array}$ & $\begin{array}{l}\text { Nominal } \\
25 \mathrm{mg} / \mathrm{mL}\end{array}$ & $\begin{array}{l}\text { Nominal } \\
10 \mathrm{mg} / \mathrm{mL}\end{array}$ \\
\hline Initial concentration, observed (mg/mL) & $27.79 \pm 0.29$ & $11.42 \pm 0.08$ & $28.83 \pm 0.15$ & $11.68 \pm 0.07$ \\
\hline 1 & $93.55 \pm 0.55$ & $92.27 \pm 0.2$ & $91.82 \pm 0.91$ & $91.03 \pm 0.38$ \\
\hline 3 & $76.74 \pm 0.24$ & $73.57 \pm 0.49$ & $72.46 \pm 1.57$ & $71.90 \pm 1.02$ \\
\hline 4 & $71.37 \pm 0.57$ & $67.33 \pm 0.85$ & $67.06 \pm 2.04$ & $64.56 \pm 0.37$ \\
\hline \multicolumn{5}{|l|}{ Data analysis } \\
\hline Degradation rate (\%/day)† & -7.407 & -8.404 & -8.523 & -9.000 \\
\hline SD from regression $(S y . x) \neq$ & 1.180 & 1.178 & 1.623 & 0.853 \\
\hline $\begin{array}{l}\text { Fastest degradation rate (\% loss/day) } \\
\text { with } 95 \% \text { confidence } \S\end{array}$ & -9.012 & -10.007 & -10.732 & -10.161 \\
\hline $\begin{array}{l}\text { Shortest T-90 (h) with 95\% } \\
\text { confidence§ }\end{array}$ & 26.63 & 23.98 & 22.36 & 23.62 \\
\hline
\end{tabular}

$\mathrm{Cl}=$ confidence interval, SD = standard deviation.

*Each value is based on duplicate determination of 3 samples. The percent remaining is based on designation of the initial measured concentration (day 0) as $100 \%$.

†The degradation rate was determined by linear regression of the percent remaining on each study day. FThe SD from the regression (Sy.x) provides an estimate of the SD about the line determined by linear regression, expressed as a percentage relative to the concentration. Expressed in this way, it is also an estimate of the between-day error of replicate analysis.

$\S$ The fastest degradation rate was determined from the lower limit of the $95 \% \mathrm{Cl}$ of the slope (percent remaining versus study day) determined by linear regression.

१T-90 is the time for the concentration to decline by $10 \%$, i.e., to $90 \%$ of the initial concentration. 
Table 3. Percentage of Azacitidine Remaining* with Storage at $-20^{\circ} \mathrm{C}$

Type of Container; Initial Concentration; Mean \% Remaining \pm SD

\begin{tabular}{|c|c|c|c|c|}
\hline \multirow[b]{3}{*}{ Study Day } & \multirow{2}{*}{\multicolumn{2}{|c|}{ Vials }} & \multirow{2}{*}{\multicolumn{2}{|c|}{ Syringes }} \\
\hline & & & & \\
\hline & $\begin{array}{l}\text { Nominal } \\
25 \mathrm{mg} / \mathrm{mL}\end{array}$ & $\begin{array}{l}\text { Nominal } \\
10 \mathrm{mg} / \mathrm{mL}\end{array}$ & $\begin{array}{l}\text { Nominal } \\
25 \mathrm{mg} / \mathrm{mL}\end{array}$ & $\begin{array}{l}\text { Nominal } \\
10 \mathrm{mg} / \mathrm{mL}\end{array}$ \\
\hline Initial concentration, observed (mg/mL) & $25.66 \pm 0.05$ & $9.99 \pm 0.05$ & $23.96 \pm 0.15$ & $9.73 \pm 0.07$ \\
\hline 1 & $95.62 \pm 1.05$ & $98.92 \pm 1.01$ & $103.76 \pm 1.06$ & $103.90 \pm 0.46$ \\
\hline 6 & $101.92 \pm 0.26$ & $96.73 \pm 2.31$ & $102.32 \pm 2.67$ & $100.95 \pm 1.89$ \\
\hline 13 & $103.54 \pm 2.39$ & $99.91 \pm 1.23$ & $101.30 \pm 2.56$ & $99.45 \pm 0.43$ \\
\hline 18 & $103.82 \pm 1.52$ & $102.42 \pm 0.88$ & $102.79 \pm 4.90$ & $104.04 \pm 0.71$ \\
\hline 20 & $104.19 \pm 0.74$ & $101.49 \pm 1.25$ & $100.88 \pm 4.25$ & $98.09 \pm 1.05$ \\
\hline 23 & $104.51 \pm 1.84$ & $99.65 \pm 0.59$ & $103.51 \pm 3.27$ & $101.63 \pm 0.05$ \\
\hline \multicolumn{5}{|l|}{ Data analysis } \\
\hline Degradation rate (\%/day)† & 0.291 & 0.103 & 0.028 & 0.036 \\
\hline SD from regression $(S y . x) \neq$ & 1.849 & 1.699 & 1.509 & 2.412 \\
\hline $\begin{array}{l}\text { Fastest degradation rate (\% loss/day) } \\
\text { with } 95 \% \text { confidence }\end{array}$ & -0.500 & -0.294 & -0.142 & -0.307 \\
\hline $\begin{array}{l}\text { Shortest T-90 (days) with 95\% } \\
\text { confidence§ }\end{array}$ & 20.01 & 34.01 & 70.59 & 32.53 \\
\hline
\end{tabular}

$\mathrm{Cl}=$ confidence interval, $\mathrm{SD}=$ standard deviation.

*Each value is based on duplicate determination of 3 samples. The percent remaining is based on designation of the initial measured concentration (day 0) as 100\%.

†The degradation rate was determined by linear regression of the percent remaining on each study day.

‡The SD from the regression (Sy.x) provides an estimate of the SD about the line determined by linear regression, expressed as a percentage relative to the concentration. Expressed in this way, it is also an estimate of the between-day error of replicate analysis.

$\S$ The fastest degradation rate was determined from the lower limit of the $95 \% \mathrm{Cl}$ of the slope (percent remaining versus study day) determined by linear regression.

१T-90 is the time for the concentration to decline by $10 \%$, i.e., to $90 \%$ of the initial concentration.

\section{DISCUSSION}

Azacitidine degradation was observed to be very sensitive to temperature. This drug degrades quickly at room temperature, but little, if any, degradation was observed in samples frozen at $-20^{\circ} \mathrm{C}$ over 23 days. Given that the study was driven by the need to reduce wastage, reconstitution of azacitidine with cold $\left(4^{\circ} \mathrm{C}\right)$ sterile water became an important step in limiting degradation, because this approach to reconstitution reduced the time that a solution remained at room temperature.

After reconstitution of azacitidine with cold sterile water $\left(4^{\circ} \mathrm{C}\right)$ and refrigerated storage, approximately $10 \%$ of the initial azacitidine concentration was lost over a 24 -h period. This is a considerably longer period than the period of refrigerated storage suggested by the current manufacturer's monograph $(8 \mathrm{~h}) .{ }^{4}$ In addition, reconstitution with cold sterile water has recently been reported by Tutino and Lai. ${ }^{6}$ However, cold-water reconstitution alone will not slow the degradation rate sufficiently to allow an azacitidine solution reconstituted on one day to be used the next. This is because, during the storage-temperature life cycle of the product, a syringe or vial of azacitidine that spends $2 \mathrm{~h}$ at room temperature must spend less than $12 \mathrm{~h}$ at $4^{\circ} \mathrm{C}$, which would not reduce wastage. Reduction of wastage requires at least some storage at $-20^{\circ} \mathrm{C}$.
For this reason, stability at $-20^{\circ} \mathrm{C}$ was also evaluated. Observed concentrations following 23 days of storage at $-20^{\circ} \mathrm{C}$ were all greater than $95 \%$ of the initial concentration, similar to the data reported by Duriez and others. ${ }^{13}$ If storage at $-20^{\circ} \mathrm{C}$ is included in the product's life cycle, such that a vial is reconstituted with cold sterile water for injection and immediately placed in a refrigerator at $4^{\circ} \mathrm{C}$, the product may remain at $4^{\circ} \mathrm{C}$ for $8 \mathrm{~h}$ (until the end of the day on which it was reconstituted). If the product is not used during that period it should then be placed in a freezer at $-20^{\circ} \mathrm{C}$. The product may remain in the freezer for up to 4 days. On the fourth day, or before the 96th hour of storage at $-20^{\circ} \mathrm{C}$, the product should be withdrawn from the freezer, thawed $(<30 \mathrm{~min})$, drawn into a syringe, and delivered for injection into the patient. If the time required for the vial to thaw, the solution to be drawn into a syringe, and the syringe delivered to the patient for injection is less than $2 \mathrm{~h}$, the product will contain, with $97.5 \%$ confidence, more than $90 \%$ of the original concentration (based on the fastest degradation rates reported in Tables, 1, 2, and 3).

\section{CONCLUSIONS}

More than $90 \%$ of the initial azacitidine concentration will be retained, with $97.5 \%$ confidence, if (during the life of 


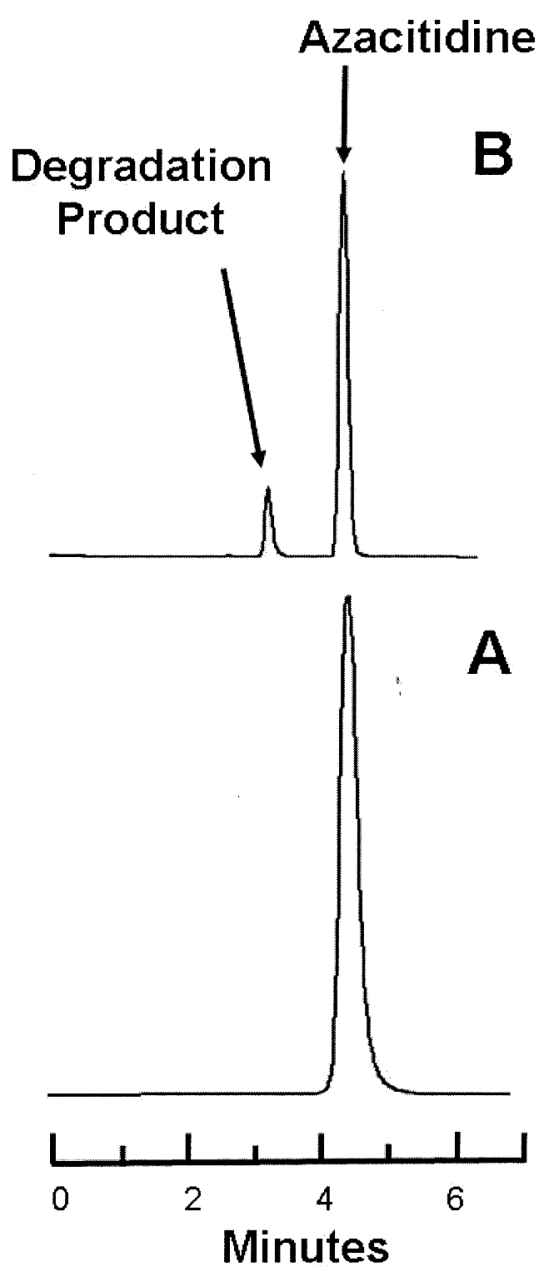

Figure 2. Representative chromatograms obtained during the stability study at $4^{\circ} \mathrm{C}$. Lower panel (A): Azacitidine $10 \mathrm{mg} / \mathrm{mL}$ in water at time 0 . Upper panel (B): The same sample of azacitidine $10 \mathrm{mg} / \mathrm{mL}$ after 3 days' storage in a glass vial at $4^{\circ} \mathrm{C}$, at which time $75 \%$ of the initial concentration remained. The major degradation product observed in the accelerated degradation study was observed in all samples stored at $4^{\circ} \mathrm{C}$.

the product) storage at $23^{\circ} \mathrm{C}$ does not exceed $2 \mathrm{~h}$, storage at $4^{\circ} \mathrm{C}$ does not exceed $8 \mathrm{~h}$, and storage at $-20^{\circ} \mathrm{C}$ does not exceed 4 days. These expiry dates can substantially reduce wastage and cost where the time between administering doses to patients does not exceed 4 days.

\section{References}

1. Kastango ES, Bradshaw BD. USP chapter 797: establishing a practice standard for compounding sterile preparations in pharmacy. Am J Health Syst Pharm 2004;61(18):1928-1938.
2. Walker SE, Hanabusa Y, Dranitsaris G, Bartle WR, Iazzetta J. Cost effective evaluation of a stability study. Can J Hosp Pharm 1987;40(4):113-118.

3. Walker SE, DeAngelis C, Iazzetta J, Gafni A. Chemotherapy waste reduction through shelf-life extension. Can J Hosp Pharm 1994;47(1):15-23.

4. VIDAZA (azacitidine for injection) for SC or IV use [product monograph]. Summit (NJ): Celgene Corporation; revised 2008 Aug.

5. Cheung YW, Vishnuvajjala BR, Morris NL, Flora KP. Stability of azacitidine in infusion fluids. Am J Hosp Pharm 1984;41(6):1156-1159.

6. Tutino A, Lai M. Cold water reconstitution of Vidaza ${ }^{\circledR}$ with subsequent refrigerated storage prolongs drug stability. Eur J Hosp Pharm Pract 2011;17(5):24-25.

7. Trissel LA. Avoiding common flaws in stability and compatibility studies of injectable drugs. Am J Hosp Pharm 1983;40(7):1159-1160.

8. Trissel LA, Flora KP. Stability studies: five years later. Am J Hosp Pharm 1988;45(7):1569-1571.

9. Policy for publication of chemical stability study manuscripts. Can J Hosp Pharm 1990;43(1):3-4.

10. Shah VP, Midha KK, Dighe S, McGilveray IJ, Skelly JP, Yacobi A, et al. Analytical methods validation: bioavailability, bioequivalence and pharmacokinetic studies. J Pharm Sci 1992;81(3):309-312.

11. Freiman JA, Chalmers TC, Smith H Jr, Kuebler RR. The importance of beta, the type II error and sample size in the design and interpretation of the randomized control trial. Survey of 71 "negative" trials. N EnglJ Med 1978;299(13):690-694.

12. Stolley PD, Strom BL. Sample size calculations for clinical pharmacology studies. Clin Pharmacol Ther 1986;39(5):489-490.

13. Duriez A, Vigneron JH, Zenier HA, May I, Demoré BM. Stability of azacitidine suspensions. Ann Pharmacother 2011;45(4):546.

Scott E Walker, MScPhm, is Director of the Department of Pharmacy, Sunnybrook Health Sciences Centre, and Associate Professor, Leslie Dan Faculty of Pharmacy, University of Toronto, Toronto, Ontario.

Lauren F Charbonneau, BSc(Pharm), is Pharmacy Manager, Odette Cancer Centre, Sunnybrook Health Sciences Centre, Toronto, Ontario.

Shirley Law, DipPharmTech, is a Research Assistant, Department of Pharmacy, Sunnybrook Health Sciences Centre, Toronto, Ontario.

Craig Earle, MD, MSC, FRCPC, is Director of the Health Services Research Program, Cancer Care Ontario and the Ontario Institute for Cancer Research, Toronto, Ontario.

\section{Address correspondence to:}

Scott E Walker

Room E305

Department of Pharmacy

Sunnybrook Health Sciences Centre

2075 Bayview Avenue

Toronto ON M5N 3M5

e-mail: scott.walker@sunnybrook.ca 